\title{
Feministisk institutionalisme og kommunal strukturreform
}

\section{Af Hanne Nexø Jensen}

\section{Mulighederne for at kombinere} feministisk institutionalisme og nyinstitutionalisme $i$ studier af forandringer $i$ offentlige organisationer bliver afsogt $i$ artiklen. Som illustrativt eksempel ev valgt faldet $i$ antallet af kvindelige kommunaldivektorer efter strukturreformens implementering $i$ kommunerne.

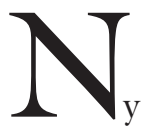

y og spændende international forskning debatterer mulighederne for at kombinere feminisme og nyinstitutionalisme og udvikle en feministisk institutionalisme. Jeg præsenterer udvalgte hovedlinjer i debatten og resultaterne samt uddyber enkelte elementer fra nyinstitutionalisme med henblik på en tentativ afsøgning af teorifeltet og dets muligheder. Som illustrativt eksempel ser jeg nærmere på faldet $\mathrm{i}$ antallet af kvindelige kommunaldirektører efter implementering af strukturreformen i de danske kommuner i januar 2007. Gængse forklaringer på, hvorfor nedgangen blev så markant bliver udfordret med elementer fra nyinstitutionalisme og feministisk institutionalisme. Jeg runder af med bud på en række forskningsspørgsmål.

FEMINISTISK INSTITUTIONALISME

- NYE VEJE?

Politik, magt og forandringer er omdrejningspunkter inden for nyinstitutionalisme, 
som netværket FIIN, The Feminism and Institutionalism International Networks medlemmer finder relevant at tilsæette et kønsperspektiv. ${ }^{1}$ Ambitionen er at kombinere nyinstitutionalisme og feminisme i studier af køn og politik, herunder at udforske interaktionen mellem aktører og institutioner med henblik på at udvikle en feministisk institutionalisme. Inden for begge -ismer bliver der peget på betydningen af både formelle og informelle institutioner, som praksisser og normer. ${ }^{2}$

Begge - ismer blev revitaliseret i 1970'erne. Både nyinstitutionalisme og feminisme dækker over et utal af tilgange. Hall og Taylor fremhæver to tværgående aspekter ved nyinstitutionalisme: (1) hvordan kan relationen mellem institutioner og handling forstås og (2) hvordan kan skabelse og forandringer af institutioner forklares? (Hall og Taylor 1996: 937). 'Institutioner' er defineret forskelligt inden for hovedstrømmene. Det er almindeligt at skelne mellem rational choice samt historisk og sociologisk nyinstitutionalisme. Senere bidrag tilføjer poststrukturalistisk nyinstitutionalisme baseret på Foucault (Gjelstrup og Sørensen 2007: 27).

Jeg afsøger tentativt mulighederne for at tilsætte nyinstitutionalisme et kønsperspektiv og bevare et fokus på magt og forandringer illustreret med faldet $\mathrm{i}$ antallet af kvindelige kommunaldirektører efter strukturreformens implementering. Qua min empiri koncentrerer jeg mig om historisk og sociologisk nyinstitutionalisme, hvor institutioner både er formelle og informelle regler, normer og procedurer, der er indlejret i strukturer og påvirker og giver mening for handling og adferd (Hall og Taylor 1996: 938, March og Olsen 1989: 160). Historisk nyinstitutionalisme opererer på et makro-niveau og inkluderer magtasymmetri. Fortidens rammer, normer og regler er bestemmende for kommende mulighedsrum for forandringer i politiske institutioner (stiafhængighed). Det kan eksempelvis være normer, der muliggør et stigende antal kvindelige ledere. Sociologisk nyinstitutionalisme opererer på et meso-niveau, og fokus er blandt andet på, hvordan individers adfærd og identitet bliver påvirket af og giver mening via institutioner. Nogle former for adfærd er legitime og andre det modsatte i givne organisationer, og det påvirker mulighederne for forandringer ('passendehedslogik'). Et eksempel på denne passendehedslogik er, at det i Norge giver mening at stille krav om flere kvinder i virksomheders bestyrelser, hvilket ikke er tilfældet på samme måde i Danmark.

Feminismens revitalisering i 1970'erne var en del af det politiske opgør med kapitalisme, krig, undertrykkelse af køn, race og etniske grupper. Et fællestræk ved de feministiske strømme er betoningen af, at verden er struktureret ulige ud fra køn og at kønsulighederne bør forandres (McGinn og Patterson 2005: 932). Drude Dahlerup har defineret feminisme

"som et idésystem, hvis formål er at fjerne diskrimination og nedvurdering af kvinder, idet man tager udgangspunkt $i$, at der eksisterer et magthierarki mellem kønnene, der er socialt konstrueret og ikke givet af Gud, biologien eller naturen”. (Dahlerup 2007: 15)

Nogle feministiske strømme betoner biologiske forskelle mellem kvinder og mænd, mens andre refererer til psykologiske variationer. Historisk materialistiske forklaringer indikerer, at sociale forhold og betingelser indvirker forskelligt på kvinder og mænd. Postmoderne tilgange betragter køn som en konstruktion, hvor mening bliver vigtig (McGinn og Patterson 2005: 932).

Nyinstitutionalisme er med rette kritiseret for at være kønsblind (Chappell 2006: 225, Kenny 2007: 96). Det kan man fra et samfundsvidenskabeligt ståsted råde bod på ved at inkludere en forståelse af, at institutioner er kønnede og køn er ikke noget vi har, men noget vi gør: Køn former institutioner og aktører og omvendt (f.eks. Con- 
nell 2004, Kenny 2007, Lovenduski 1998, Chappell 2006: 225).

Meryl Kenny bidrager til at videreudvikle feministisk institutionalisme ved at pege på tre fællestræk ved feminisme og nyinstitutionalisme:

(1) neutralitet dækker over, at nogle grupper opnår privilegier på bekostning af andre (2) begge forklarer institutioners dannelse, kontinuitet, modstand og forandring og

(3) understreger magtrelationers historicitet, muligheden af institutionel modstand og magtskifte. (Kenny 2007: 95)

Kenny finder, at nyinstitutionalisme kan bidrage til forståelse af kontinuitet, forandring, modstand og passende adfærd samt kan forklare, hvorfor nogle normer bliver forhandlet, mens andre ikke gør. Historisk nyinstitutionalisme anerkender eksistensen af asymmetriske magtrelationer, men køn er ikke ekspliciteret som en komponent. Magt, magtrelationer og forandringsmuligheder (empowerment) er feminismens særlige bidrag (Kenny 2007: 95f).

Der er eksempler på forskere, der foruden inspiration fra historisk og sociologisk nyinstitutionalisme udforsker mulighederne for at finde koblinger mellem rational choice eller diskursiv nyinstitutionalisme samt feminisme. ${ }^{3}$ Overordnet tematiserer de feministiske forskere deres analyser ud fra de samme to temaer, der kendetegner nyinstitutionalismen som sådan: dels relationen mellem institutioner og handling, dels forandringer og modstand.

Emnemæssigt spænder de feministiske forskere bredt inden for køn og politiske institutioner. ${ }^{4}$ Jeg fokuserer på dem, der er adresseret offentlig forvaltning, f.eks. i form af politiske institutioner. Skelner man mellem normative, empiriske og konstruktive tilgange (Lundquist 1993: 60-65), er det kun Chappell, der har en eksplicit normativ tilgang, da hun ønsker at finde ud af, hvordan offentlige institutioner $b ø r$ være for at fungere mest effektivt set fra femo- kraters vinkel (Chappell 2006). De øvrige spørger empirisk, hvordan normer og sanktioner kan støtte homoseksuelle grupper, eller hvordan politiske institutioner er kønnede samt til politikeres repræsentation og muligheder for at gennemføre ligestillingspolitik (Kenney 1996, Lovenduski 1998, Monro 2007).

Metodisk slår Chappell (2006) til lyd for komparative studier, mens Kenney fremhæver, at variation i dataindsamlingsmetoder er godt (Kenney 1996). I nogle studier bliver begreber fra flere tilgange, f.eks. historisk og sociologisk nyinstitutionalisme kombineret (Chappell 2006).

Feministisk institutionalisme er en bredtfavnende hat, både hvad angår emner, metoder og forskningens sigte. F.eks. er der få, der ekspliciterer deres normative afsæt. I studierne fremstår forskningsspørgsmålet som empirisk, selvom det er styret af et ønske om at forandre. Det giver forrang til nogle konklusioner frem for andre (f.eks. Kenney 1996, Monro 2007). Begrundelser for valg af ét eller elementer fra flere nyinstitutionelle retninger er ofte fraværende. Monro skriver, at hun udfylder et hul i litteraturen, når hun kombinerer kommuner, ligestillingsarbejde, partnerskab og sociologisk nyinstitutionalisme (Monro 2007: 2). Chappell skriver, at hun bruger historisk nyinstitutionelle begreber samtidig med, at hun i praksis inkluderer elementer fra sociologisk nyinstitutionalisme (Chappell 2006). Jeg finder det relevant at begrunde valg af begreber og retninger, da det viser, hvilket analyseniveau vi befinder os på og giver mulighed for at diskutere forskningsresultaterne i lyset af de trufne valg.

Vi har meget "lidt viden om de kønnede processer, der organiserer og konstituerer offentlig forvaltning" (McGinn og Patterson 2005: 941). Der er behov for nytænkning, når vi skal forstå udviklingen i offentlige organisationer i et kønsperspektiv. Det er en stor udfordring at få operationaliseret begreber fra nyinstitutionelle tilgange og begreber om køn og magt til brug i empiri- 
ske analyser. Feministisk institutionalisme har inspireret mig til at inddrage nyinstitutionelle kategorier i studiet af kønnede processer i offentlige organisationer. Dette adskiller sig fra f.eks. Due Billing, der fokuserer på individer og organisationskultur og ikke ekspliciterer det offentlige aspekt såvel som samspillet mellem institutioner og handling som i nyinstitutionalismen (Billing 2005). Et særtræk ved mit illustrative eksempel er, at det er et markant brud, som historiske nyinstitutionalister har skabt muligheder for at udforske. Tilsvarende er der brug for at udforske individers adfærd på organisationsniveau, og her kan sociologisk nyinstitutionalisme bidrage. Når det handler om studier af køn i organisationer er feministisk institutionalisme nødvendig men utilstrækkelig. Der må suppleres med tilgange, der har fokus på kønnede processer i offentlige organisationer.

\section{STRUKTURREFORMEN I \\ ET KØNSPERSPEKTIV}

Strukturreformen betød, at to tredjedele af de eksisterende 275 kommuner blev lagt sammen til 98. Mange opgaver blev flyttet fra amter til kommuner, f.eks. på socialområdet, specialundervisning og miljø. Veje og kultur blev rykket fra amter til staten. Der er etableret jobcentre, hvor stat og kommuner samarbejder. Staten har overtaget skatteopkrævning og uddannelsesinstitutioner er blevet selvejende (KL 2005).

Strukturreformen har glimret ved en manglende hensyntagen til ligestilling. Ligestillingsloven tilsiger som bekendt, at der skal være en ligelig repræsentation af kvinder og mænd i offentlige råd, nævn og udvalg. Kommissionen, der udarbejdede et beslutningsgrundlag for xndringer i organiseringen af den offentlige sektor, bestod af 13 mænd og 1 kvinde (Christensen 2005). Ligestilling indgik heller ikke i kommissoriet, selvom offentlige myndigheder er forpligtet til at kønsmainstreame, dvs. at " $k ø n$ og ligestilling skal tænkes ind $i$ alle of- fentlige beslutninger og tiltag” (Dansk Kvindesamfund 2005). Reformens implementering indebar et markant fald i antallet af kvindelige kommunaldirektører. En mere ligelig kønsfordeling vil i sig selv ikke føre til ændringer, men mangfoldighed er fra flere sider fremhævet som kvalificerende for opgaveløsningen (Bøgelund 2008, Christensen 2007, Rambøll 2007).

I det følgende dokumenterer jeg først faldet, og dernæst bliver tallene som illustrativt eksempel sat i spil med to fremherskende forklaringer på det skete. Endelig afsøger jeg tentativt, hvad en kobling af nyinstitutionalisme og feminisme kan bidrage med og formulerer forskningsspørgsmål med henblik på at forstå det faldende antal kvindelige kommunaldirektører.

\section{DOKUMENTATION FOR FÆRRE KVINDELIGE KOMMUNALDIREKTØRER}

Under ét er der flere kvinder end mænd ansat i landets kommuner. Det gælder dog ikke på direktionsniveauet, der har hovedansvaret for at servicere politikerne og sikre, at politiske beslutninger bliver gennemført til gavn for borgerne og samfundet. I september 2008 var knap hver femte direktionsmedlem kvinde, og der var fire kvindelige kommunaldirektører ud af 98 (fire procent) (tabel 1). Næsten to ud af fem kommuner havde ingen kvinder i direktionen.

Kvinderepræsentationen i direktionerne er næsten dobbelt så høj i de 'gamle' ikke sammenlagte kommuner jævnført med de 'nye' sammenlagte kommuner. Dvs., der, hvor organisationen er ændret mest markant, er slutresultatet blevet færre kvinder, mens kvindeandelen er øget i de ikke-sammenlagte kommuner (tabel 1). ${ }^{5}$ Af de 30 kvinder, der var kommunaldirektører i 2006 fortsatte fire, heraf tre i sammenlagte kommuner.

I 2008 er 38 procent af de tidligere kvindelige kommunaldirektører medlem af en kommunal direktion, mens tallet for de tidligere mandlige kommunaldirektører er 58 
TABEL 1. ANDEL AF KVINDER OG MÆND I DE KOMMUNALE DIREKTIONER FØR OG EFTER STRUKTURREFORMENS IVÆRKSÆTTELSE (KOMMUNAL ÅRBOG 2006, 2008 ).

2006

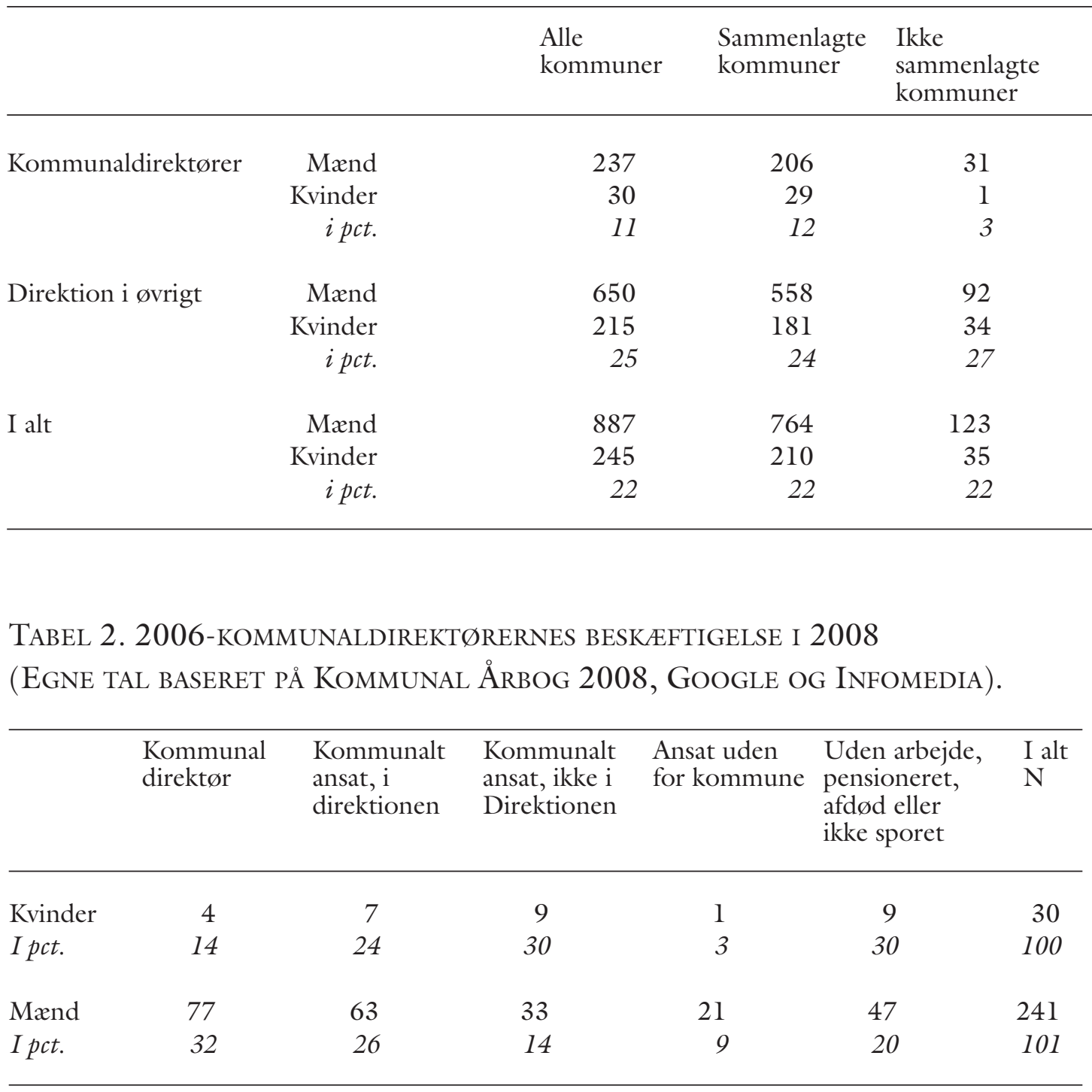

procent. Dobbelt så mange kvinder som mænd har takket ja til et kommunalt job, hvor de ikke indgår i direktionen (30 procent kvinder mod 14 procent mænd). Lidt over en tredjedel af de tidligere kvindelige kommunaldirektører og knap en femtedel af de mandlige er enten uden job eller har ikke været mulige at spore (tabel 2).

\section{ILLUSTRATIVT EKSEMPEL}

I offentligheden er der to gennemgående forklaringer på den lave kvindeandel blandt de nyudnævnte kommunaldirektører. Den ene er, at de hidtidige direktører skal tilbydes en passende stilling. ${ }^{6}$ Mange kommuner har derfor gjort brug af interne opslag, hvorfor det er "en naturlig udvikling, at an- 
2008

Alle

kommuner
Sammenlagte Ikke

kommuner sammenlagte kommuner

$\begin{array}{rrr}94 & 63 & 31 \\ 4 & 3 & 1 \\ 4 & 4,5 & 3 \\ 325 & 230 & 95 \\ 92 & 48 & 44 \\ 22 & 17 & 32 \\ 419 & 293 & 123 \\ 96 & 51 & 45 \\ 19 & 15 & 27\end{array}$

tallet af kvindelige ledere på landsplan skrumper" ifølge kommunaldirektøren i Aabenraa Kommune (Kaas 2006). Der var flere mænd end kvinder på kommunaldirektørniveau, der skulle have tilbudt job (Bøgelund 2006), og formanden for Kommunernes Landsforenings løn- og personaleudvalg, Mads Lebech siger: “.. man har i stor udstrækning valgt at rekruttere fra de kort, der lå på bordet" (Pihl-Andersen \& Olesen 2008). Det forklarer dog ikke, hvorfor mænd har været mere succesfulde med at få et tilsvarende job end kvinder, jævnføre overgangsraterne på 32 procent for mænd og 14 procent for kvinder i alle kommuner. Det forklarer heller ikke, hvorfor kvinder i mindre grad end mænd er tilbudt job på samme niveau, jevnført det samlede tal for tidligere kommunaldirektører i de nye direktioner, hvor knap to femte dele af kvinderne og tre femtedele af mændene er fortsat i en direktion (tabel 2).

Den anden hovedforklaring er, at man ved ansættelse har ønsket at fortsætte med

'kendte kræfter', da 'sikker drift' har været et mantra (Bøgelund 2006, Olesen og PihlAndersen 2008). F.eks. udtaler Aabenraas kommunaldirektør, at "der var kun omkring fem procent kvinder i ansøgerfeltet.... men vi skulle altså tage de bedst kvalificerede" (Kaas 2006). Det er ikke ekspliciteret, hvad 'bedst kvalificeret' vil sige. Henrik Ludolph, der er formand for de offentlige chefer har udtalt: "Politikerne har valgt det, de betragter som sikre kort, nemlig kommunaldirektører med erfaring fra de store kommuner." (Friis 2006). Her er der klart flere mænd at tage af, da mange kvinder har ledet mindre kommuner. Det er uvist, hvor mange kvinder, der har søgt en stilling som kommunaldirektør, men der har været kvinder med erfaring på kommunalt toplederniveau. Uanset hvad, kan det undre, at fokus er på 'sikker drift' frem for på erfaringer med at håndtere fusioner.

På det kommunale område er der røster fremme om, at det blot er et spørgsmål om tid, før vi ser flere kvindelige kommunaldirektører og kvinder i de kommunale direktioner som sådan (Bøgelund 2006, Friis 2006, Pihl-Andersen og Olesen 2008). I efteråret 2008 er ansat yderligere to kvindelige kommunaldirektører, dermed er kvindeandelen på seks procent. En undersøgelse fra Århus Kommune viser, at flere kvinder i rekrutteringslaget ikke nødvendigvis resulterer $\mathrm{i}$ flere kvinder på topposterne. F.eks. appellerer flere stillingsopslag til mænd end til kvinder og allerede ansatte kvinder undlader at søge internt. Manglen på kvindelige rollemodeller er også et problem (Rambøll 2007). Dertil kommer, at flere kommuner er begyndt at slanke direktionerne. På Bornholm er direktionen reduceret fra syv til to. Frederikssund og Slagelse Kommuners direktioner er reduceret med to, så de nu er på fem personer. Der er også eksempler på kommuner, der sparer chefer væk (Olesen og Pihl-Andersen 2008).

Der er oplagt et behov for at opnå en dyb forståelse af de institutionelle normer 
og værdier, der er afgørende for, om den kommunale implementering af strukturreformen fører til et fald $\mathrm{i}$ antallet af kvinder på det kommunale ledelsesniveau, når den eksisterende kønsfordeling kunne være fastholdt. Blandt andet i lyset af, at den offentlige debat om ligestilling i bestyrelser ikke har ført til lovindgreb som i Norge. Der er i Folketinget ikke politisk flertal for kønskvotering (Kudahl 2008), tværtimod er signalet, at ligestilling skal komme ad frivillighedens vej. Seneste initiativ fra ligestillingsministeren er en invitation til virksomheder til at skrive under på Charter for flere kvinder i ledelse (Ligestillingsministeriet 2008). Oppositionen og andre mener, at der skal en mere aktiv indsats til for at øge kvindeandelen blandt ledere og i politik. ${ }^{7}$

\section{TentaTIV AFs $\varnothing$ GNING AF \\ NYT TEORIFELT}

I en historisk nyinstitutionel optik er fokus bl.a. på at afdække, hvilke normer og værdier fra tidligere, der overlever og hvilke, der bliver skrottet. For 25 år siden udgjorde kvinderne én procent af de kommunale topledere, cirka 10 år senere i 1992 var otte procent kvinder (Fiig 1999: 38). Set over tid kan man argumentere for, at det stigende antal kvindelige chefer spejler de samfundsmæssige værdier og normer, der trækker i retning af øget ligestilling, om end det er gået trægt i kommunerne. Stiafhængighed skulle tilskrive, at stigningen $\mathrm{i}$ andelen af kvinder kunne fortsætte. Imidlertid får strukturreformens implementering karakter af 'et kritisk øjeblik' (Hall og Taylor 1996: 942), hvor der sker et markant brud med hidtidige praksisser og et opgør med gxldende normer og værdier med færre kvindelige kommunaldirektører som resultat, i øvrigt svarende til tilbagegangen for australske femokrater (Sawer 2007). Strukturreformen i et kønsperspektiv viser, at institutioner ikke er givne. De skabes, genskabes og forandres til stadighed. Hall og Taylor fremhæver magtasymmetri som vigtig.
Strukturreformen har ført til forskydninger i eksisterende kønnede magtbalancer, gennem forskelsbehandling af mænd og kvinder.

Overordnet handler nyinstitutionalisme om at analysere relationen mellem institutioner og handlinger. I mit eksempel er 'handlingen' den forandringsproces, der ligger forud for, at der er ansat flere mænd end kvinder i de nye kommuner. 'Institutioner' er både formelle og informelle regler, normer og procedurer, der er indlejret i strukturer og påvirker og giver mening for handlinger og adfærd, f.eks. i sammenlægningsudvalgene, der skulle besætte stillingerne i de nye kommuner (Hall og Taylor 1996: 938, March og Olsen 1989: 160). Nogle af de argumenter, der indgik i processen forud for valget af mænd er: personalejura (regler) og 'den bedst kvalificeret' (uformel norm) samt 'sikker drift' (uformel norm), men dermed forbigås ligestillingspolitik (kan være formel norm). Personalejuraen tilskriver, at man ikke må forfremme en person ved interne opslag og man skal tilbyde ledere en passende stilling ved sammenlægninger (se note 6). Der var tidligere 30 kvindelige kommunaldirektører og kun fire var ansat i 2008. Der var altså mulighed for at ansætte kvinder internt uden at forfremme dem. Personalejuraen er derfor ikke en gangbar forklaring og slet ikke i lyset af at der er mange flere mænd, der får job på samme niveau sammenholdt med kvinderne.

Sociologiske nyinstitutionalister fremhæver, at en organisation adopterer en ny praksis, fordi det øger den sociale legitimitet i en bredere kulturel kontekst. Institutionelle praksisser opstår og forandres i lyset af, hvad der giver mening og er mest passende (Hall og Taylor 1996: 949). Et bud på, hvad der kan øge den sociale legitimitet ved at ansætte mænd frem for kvinder kan være, at mænd med ledelseserfaringer fra større kommuner signalerer sikkerhed i omverdenen uanset deres kompetencer i forhold til at få sammenlagte enheder til at fungere. 
Min analyse viser, at der er sket et brud med hidtidige praksisser og normer i de nye sammenlagte kommuner, hvor eksisterende kønnede magtbalancer er forrykket på kvinders bekostning. En måde at sikre legitimitet på i omverdenen har været at ansætte mænd. Det ville være oplagt at indsamle data med henblik på at komme bagom magtrelationerne og få indblik i, hvordan det blev afgjort of af hvem. Derudover kunne det belyses, hvad det enkelte ansættelsesudvalg i sin tid forstod ved 'bedst kvalificeret' og 'sikker drift'?

Der er også behov for at få synliggjort kønsperspektivet i analyserne. Det er en udfordring at komme videre med en kombination af nyinstitutionelle tilgange og køn, hvor køn er operationaliseret til brug i empiriske analyser. Det er væsentligt, men utilstrækkeligt at få ekspliciteret magt og magtrelationer, som historisk nyinstitutionalisme lægger op til. Den australske forsker Connells tilgang til at forstå offentlige organisationers måde at håndtere køn på, kan måske bygge bro. Connell forstår køn som en struktur af sociale relationer, der skabes og genskabes her og nu (Connell 2004: 54f). Mønstre af kønsrelationer udgør en 'kønsorden' på det samfundsmæssige niveau og et 'kønssystem' på organisationsniveau. Et kønssystem er "det overordnede mønster af kønsrelationer i en organisation" (Connell 2006: 839). En organisations kønssystem kan man indkredse gennem fire dimensioner: kønsarbejdsdeling; magtmæssige kønsrelationer (f.eks. kontrol og autoritet knyttet til køn); emotionelle og menneskelige relationer samt kønskultur og symbolisme (Connell 2006: 839). De fire dimensioner er et bud på at synliggøre køn i organisationer.

I forbindelse med kortlægning af kønsarbejdsdeling i en organisation, er det f.eks. relevant at sikre viden om, der er særlige forhold ved den offentlige, kommunale forvaltning, der fremmer eller hæmmer kvinders muligheder for at blive direktører. Det kan være forskelle i kvinder og mænds ud- dannelsesbaggrund og karriereforløb i øvrigt. Er det f.eks. sådan, at flere mænd end kvinder har en akademisk generalistuddannelse, og flere kvinder end mænd har erfaringer fra sektorforvaltninger, hvor det fagspecifikke fundament er centralt og hvor et vigtigt aspekt ofte er, at borgeren er i centrum? Bliver generalistkvalifikationer anset for mere relevante end fagspecikke erfaringer?

Magtmæssige relationer kan udforskes over tid i en historisk institutionel optik. Hvilke normer og værdier har overlevet i de nye kommuner og hvilke magtmæssige kønsrelationer er de udtryk for? Der skal yderligere fokus på køn i relation til institutioner, forstået som regler, normer og procedurer indlejret i strukturer, som giver mening til og er bestemmende for aktørers handlinger. Aspekter fra sociologisk nyinstitutionalisme, som er taget op i artiklen kan danne et afsæe, der kan kobles med begrebet kønsrelationsstruktur, dvs. "den måde, hvorpå køn allerede er indlejret i en given struktur eller proces ... i en organisations struktur eller organisatoriske processer" (Jensen 1998: 165f). Er der f.eks. forskel på, hvordan kønsrelationsstrukturen er i udvalgte kommuner?

\section{AFrunding}

Der er oplagte potentialer $i$ at fortsætte med at udvikle feministisk institutionalisme $\mathrm{i}$ form af at kombinere nyinstitutionalisme og feminisme i konkrete studier. Min tentative afprøvning af idéen $\mathrm{i}$ forhold til det drastiske fald $\mathrm{i}$ antallet af kvindelige kommunaldirektører efter implementeringen af strukturreformen i januar 2007 viser, at mediernes forklaringer kan problematiseres ud fra nyinstitutionelle og feministiske optikker.

I sin nuværende form fremstår de feministiske, institutionelle bidrag dog som ufuldstændige. Der er brug for yderligere teoriudvikling af, hvordan forskellige elementer fra flere nyinstitutionelle tilgange kan kob- 
les i et og samme studie. En særlig teoretisk udfordring er, at koble nyinstitutionelle begreber med begreber om køn og magt. Der er behov for, at feministiske bidragydere inkluderer både kvinder og mænd samt relationerne mellem dem i konkrete studier. Endvidere er offentlig forvaltning et relativt uudforsket felt, hvorfor operationalisering og tilgange til studier af køn i offentlige organisationer er nødvendig.

I arbejdet med at få en dybere forståelse for, hvordan køn er på spil i offentlige forvaltninger er der mange mulige veje og forskningsspørgsmål, der er relevante at tage op. Det er oplagt at prøve at komme bagom magtrelationerne i de nye kommuner og f.eks. få indblik i, hvordan det afgøres, hvad der forstås ved 'bedst kvalificeret' og 'sikker drift'? Det er fortsat relevant at undersøge, om der er særlige forhold ved en kommunal offentlig forvaltning, der fremmer eller hæmmer kvinders muligheder for at blive direktører? Hvilke normer, værdier og procedurer har overlevet i de nye kommuner og mere specifikt, hvilke magtmæssige kønsrelationer er de udtryk for? Er der store forskelle på kønsrelationsstrukturen - eller med andre ord - den måde køn 'gøres på' i de enkelte kommuner?

\section{Noter}

1. Se omtale på FIINs hjemmeside:

http://www.femfiin.com/about-us (læst 19/9/2008).

2. Omtalen af de to - ismer er på ingen måde udtømmende. Teksten tjener som ramme for, hvad jeg fokuserer på inden for de enorme forskningsfelter som nyinstitutionalisme og feminisme er. 3. Bl.a. deltagerne i ECPR-workshoppen: Gender, Politics and Institutions: Towards a Feminist Institutionalism? Rennes, april 2008.

4. Workshopbidragene på ECPR-konferencen (se note 3 ) dækkede kvindebevægelser, statsfeminisme, velfærdsstater, forvaltning på forskellige niveauer, forfatningspolitik, transition til demokrati, rekruttering og selektion af politiske kandidater, lovgivningsadfærd samt politiske normer og idéer.
5 . Den samme tendens viste sig ved kommunalvalget i 2005, hvor kvindeandelen faldt i de sammenlagte kommuner (Dahlerup 2008: 10).

6. Se Tjenestemandsregulativ af 2004 for kommuner inden for KL's forhandlingsområde $\$ 5 \mathrm{og} 12$. 7. Et lille udpluk af røster: Egekvist \& Rysgaard 2008, Kudahl 2008, Skadhede 2008.

\section{LITTERATUR}

- Billing, Yvonne Due (2005): Ledere under forandring? - om kvinder og identitet $i$ chefjobs. Juristog Økonomforbundets Forlag. København.

- Bøgelund, Eva (2008): Et kig bagom myterne, i DJØF Bladet 2008/16.

- Bøgelund, Eva (2006): Kvinderne tabte chefkabalen i kommunerne, i DJØF Bladet 2006/13. - Chappell, Louise (2006): Comparing Political Institutions: Revealing the Gendered 'Logic of Appropriateness', i Politics \& Gender 2(2).

- Christensen, Ann-Dorte (2007): Cowboys og kavalergange i toppolitik. Morgenavisen Jyllands-Posten. $1 / 3 / 2007$.

- Christensen, Ann-Dorte (2005): Konsperspektiv på kommunalreformen - brugere, ansatte og den politiske reprasentation. Oplæg på Kvinderådets generalforsamling d. 3. april 2005.

- Connell, Raewyn (2006): Glass Ceilings or Gendered Institutions. Mapping the Gender Regimes of Public Sector Worksites, i Public Administration Review 66(6).

. Connell, Robert W. (2004): Gender. Polity Press, Cambridge.

- Dahlerup, Drude (2008): Glasloft-landet. Udvikling i kvinderepræsentationen i Danmark i et nordisk og globalt perspektiv i Festskrift for 100-året for kvinders valgret. http://www.kvinfo.dk/side/939. 23/10/2008.

- Dahlerup, Drude (2007): Ligestillingsforståelser i svenske og danske partier - er en borgerlig ligestillingspolitik under udvikling? i Tidsskriftet Politik (3).

- Dansk Kvindesamfund (2005): Den manglende ligestilling i strukturreformen. http://www.kvindesamfund.dk/valg/ligestilling_strukturreform_2005.html

· Egekvist, Kirsten S. \& Rysgaard, Kåre K. (2008): Baggrund: Stadig langt til ligestilling i toppen. Politiken. 8/7/2008.

- Friis, Lars (2006): Kun seks kvinder på toppen, i HK/Kommunal. 18/5/2006. Lokaliseret på: http://www.hkkommunal.dk/sw51764.asp

- Fiig, Christina (1999): Behandler man folk lige 
nair man behandler dem ens? Rapport fra Ligestillingsrådets høring om positiv serbehandling den 26. november 1998. Ligestillingsrådet, København.

. Gjelstrup, Gunnar \& Sørensen, Eva (2007): Introduction. I Gunnar Gjelstrup \& Eva Sørensen (eds.): Public Administration in Transition, Theory, Practice, Methodology. DJØF Publishing, Copenhagen.

- Hall, Peter A. \& Taylor, Rosemary, C.R. (1996): Political Science and the Three new Institutionalisms, i Political Studies 29.

- Jensen, Hanne Nexø (1998): Gender as the dynamo: when public organizations have to change. I Drude von der Fehr, Anna G. Jónasdóttir \& Bente Rosenbeck (eds.): Is there a Nordic Feminism? UCL Press, London.

- Kenney, Sally J. (1996): New Research on Gendered Political Institutions, i Political Research Quarterly 49 (2).

- Kenny, Meryl (2007): Gender, Institutions and Power: A Critical Review, i Politics 27 (2).

- KL (2005): Fakta om opgave- og strukturreformen - kort fortalt. Købehavn. Kommunernes Landsforening.

- Kommunal Årbog (2006). Vedbæk.

- Kommunal Årbog (2008). Vedbæk.

- Kudahl, Søren (2008): Kvoter er ikke kun for fisk, i Ugebrevet A4. 18/7/2007.

- Kaas, Tommy (2006): Bedre i næste geled, i $M a-$ gasinet Lederne, 6/7.

- Ligestillingsministeriet (2008): Charter for flere kvinder $i$ ledelse. Lokaliseret 22/8/2008 på

www.kvinderiledelse.dk/charter.asp.

- Lovenduski, Joni (1998): Gendering research in Political Science, i Annual Review of Political Science 1 .

- Lundquist, Lennart (1993): Det vetenskapliga studiet av politik. Studentlitteratur, Lund.

- March, James G. \& Olsen, Johan P. (1989): Rediscovering Institutions: the Organizational Basis of Politics. Free Press, New York.

- McGinn, Kathy \& Patterson, Patricia M. (2005): 'A Long Way Toward What?' Sex, Gender, Feminism, and the Study of Public Administration, i International Journal of Public Administration 28.

- Monro, Surya (2007): New institutionalism and Sexuality at Work in Local Government, i Gender, Work and Organization 14(1).
· Olesen, Henrik V. \& Pihl-Andersen, Axel (2008): Kommunerne rydder op i toppen. Morgenavisen Jyllands-Posten. 8/1/2008.

- Pihl-Andersen, Axel \& Olesen, Henrik V. (2008): Kvinderne tabte kampen om chefjob. Morgenavisen Jyllands-Posten. 11/1/2008.

- Rambøll Management (2007): Århus Kommune. Ledelse og køn. Barriever og muligheder for flere kvinder $i$ den overste ledelse $i$ Århus Kommune.

København.

- Sawer, Marian (2007): Australia: the Fall of the Femocrat. I Joyce Outshoorn \& Johanna Kantola (eds.): Changing State Feminism. Palgrav MacMillan. Hampshire.

- Skadhede, Jørgen (2008): Ny forening kæmper for ligestilling i bestyrelser. TV2/Finans Online 18/8/2008. Lokaliseret på www.infomedia.dk.

\section{SUMMARY}

Feminist institutionalism and local government reform

275 Danish municipalities were amalgamated into 98 in January 2007 and the percentages of female city managers were reduced drastically. I demonstrate how a combination of gender studies and new institutionalism contribute to an understanding of the gendered development in the municipalities. This is inspired by FIIN, The Feminism and Institutionalism International Network which was formed in order to contribute to studies of gender, politics, power and change combining elements from feminism and new institutionalism. Furthermore, I discuss the weak points in the theoretical contributions and suggest some possibilities of improvements in relation to studies of public organisations undergoing change.

Hanne Nexø Jensen, Lektor, ph.d.

Institut for Statskundskab

Københavns Universitet 
"Det er jo en forferdelig masse billeder,

jeg har fäet samlet sammen her.

Jeg ved saimend ikke. Det er galt med den vagplads.

Det er håblost at bygge siges der af de, der har forstand på det.

Men måske kommer der nogen, som har endnu mere forstand,

og så bliver der måske håb om at bygge...”

(lydspor fra interview med Anna Klindt Sørensen, 1976) 